\title{
Detection of IgG and IgA Antibodies of Helicobacter Pylori Seroprevalence in Hepatitis C Virus Infection
}

\author{
Osama H Al-Jiffri* and Fadwa M Alsharif \\ Department of Medical Laboratory Technology, King Abdulaziz University, Saudi Arabia
}

Submission: February 16, 2017; Published: April 13, 2017

*Corresponding author: Osama H Al-jiffri, Department of Medical Laboratory Technology, Faculty of Applied Medical Sciences, King Abdulaziz University, P.O. Box 80324, Jeddah, 21589, Saudi Arabia, Email: salmuzain@kau.edu.sa

\begin{abstract}
Background: Globally, Helicobacter pylori (H. pylori) and hepatitis C virus (HCV) are the most common bacterial infection and viral infection respectively that are associated with wide range of complications include liver cirrhosis and liver failure.

Objective: This study was designed to detect sero prevalence of H. pylori IgG and IgA antibodies among patients with HCV.

Subjects and Methods: Two hundred HCV patients of both sexes participated in this study, they were enrolled in two equal groups where group (A) include HCV patients with liver cirrhosis, while group (B) include HCV patients without liver cirrhosis.
\end{abstract}

Results: The findings of this study revealed that the H. pylori infection prevalence was a higher in group (A) that included HCV patients with liver cirrhosis than group (B) that included HCV patients without liver cirrhosis, also the sero-prevalence test of IgG and IgA showed a high significant difference between both groups.

Conclusion: Helicobacter pylori infection antibodies are more prevalent among cirrhotic HCV patients than without cirrhosis.

Keywords: Chronic hepatitis C; Cirrhosis; Helicobacter pylori; Liver disease

\section{Introduction}

Helicobacter pylori (H. pylori) constitute the commonest infection among human being as it affects about $2 / 3$ of population worldwide [1]. In addition, more than 185 million subjects are affected with chronic hepatitis $\mathrm{C}$ virus (HCV) infection worldwide [2] and cirrhosis is the late stage of progressive hepatic fibrosis among patients with hepatitis, where there are many risk factors that lead to progression of hepatitis is important for prevention of its occurrence [3]. While hepatitis C virus infection (HCV) and hepatitis $\mathrm{C}$ virus infection (HBV) are of these factors, excess alcohol consumption, male gender and schistosomiasis [4].

Helicobacter pylorus is common to be associated with pathogenesis of hepatic disorders [5-7] as it play an essential role in progression of viral hepatitis lesion to liver cirrhosis [8] as $H$. pylori secrete some hepatic specific toxin that damage liver parenchyma and causes hepatocyte necrosis that induce liver cirrhosis and hepatic cancer [9-12].

In the other hand, patients with hepatic cirrhosis are at risk for some gastrointestinal disorders where $H$. pylori infection is a principal factor in gastric ulcer pathogenesis [13]. In addition,
H. pylori antibodies were detected in HCV patients with hepatic cancer [14]. Moreover, about 30\% of patients suffer from gastric ulcer and hepatic cirrhosis had H. pylori infection [15]. Therefore, this study was designed to detect seroprevalence of H. pylori antibodies among patients with HCV.

\section{Subjects and Methods}

Two hundred consecutive HCV-positive patients (124 male and 76 female, age range 32-50 years) attending outpatient clinic, King abdulaziz university teaching hospital were enrolled in the present study to determine anti-H. Pylori antibodies presence in their serum. All participants underwent biochemical, histological and clinical evaluation to detect hepatic cirrhosis. Exclusion criteria included other hepatic disorders as hepatitis $B$ virus infection (HBV), diabetes, autoimmune and endocrine disorders. They were enrolled in two study groups: Group (A) one hundred HCV-positive cirrhotic patients (64 male and 36 female, age range 33-48 years) and Group (B) one hundred HCV-positive non-cirrhotic patients ( 60 male and 40 female, age range 32-49 years). The Scientific Ethical Research Committee of Faculty of Applied Medical Sciences approved this study. 
All participants singed the consent form before sharing in the present study.

Detection of serum anti-H. pylori (IgG and IgA) antibodies was done with a commercial enzyme-linked immunosorbent assay (ELISA) (Helori-test $®$ Eurospital, Trieste, Italy) . However, ELISA (Axsym System, Abbott Diagnostics) and an RIBA (RIBA II, LIA, HCV3, Sorin, Saluggia, Italy) were used to diagnose HCV infection and confirmed using polymerase chain reaction (PCR) to confirmed circulating HCV-RNA detection.

\section{Results}

Table 1: Baseline and laboratory data of all participants.

\begin{tabular}{|c|c|}
\hline Demographic and Laboratory Data & Median (Range) \\
\hline Age mean age \pm SD (range) & $40.32 \pm 6.45(32-50)$ \\
\hline Gender (male/female) & $124 / 76$ \\
\hline ALT mean \pm SD (range) & $58.42 \pm 13.51(30-87)$ \\
\hline AST mean \pm SD (range) & $47.31 \pm 11.35(25-65)$ \\
\hline Total bilirubin mean \pm SD (range) & $0.83 \pm 0.17(0.52-1.1)$ \\
\hline Platelets & $167,460(12,000-225,000)$ \\
\hline Albumin & $4.7(4.0-5.2)$ \\
\hline HCV RNA titre & $340,000(50,700-7430,000)$ \\
\hline
\end{tabular}

Two hundred HCV patients were selected on referral to Gastroenterology and Hepatology Department, King Abdulaziz University Teaching Hospital, all these patients were anti HCV positive by ELISA. Patient characteristics (Table 1). The findings of this study revealed that the $H$. pylori infection prevalence was higher in group (A) that included HCV patients with liver cirrhosis than group (B) that included HCV patients without liver cirrhosis, also the sero-prevalence test of IgG and IgA showed a high significant difference between both groups (Table $2 \& 3$ ).

Table 2: Number and percentage of $H$. Pylori IgG and IgA positivity and negativity in the cirrhotic and non-cirrhotic groups.

\begin{tabular}{|c|c|c|c|c|}
\hline & \multicolumn{2}{|c|}{ Number (\%) } & \multirow{2}{*}{ T-value } & P-value \\
\cline { 2 - 3 } & Cirrhotic group & $\begin{array}{c}\text { Non-cirrhotic } \\
\text { group }\end{array}$ & & \\
\hline IgG positive & $100(100 \%)$ & $84(84 \%)$ & \multirow{2}{*}{10.43} & $\mathrm{P}<0.05$ \\
\hline IgG negative & $0(0 \%)$ & $16(16 \%)$ & & \\
\hline IgA positive & $72(72 \%)$ & $48(48 \%)$ & \multirow{2}{*}{12.67} & $\mathrm{P}<0.05$ \\
\hline IgA negative & $28(28 \%)$ & $52(52 \%)$ & & \\
\hline
\end{tabular}

Table 3: Comparison between $\mathrm{H}$. Pylori IgG and IgA serological test in the cirrhotic and non-cirrhotic groups.

\begin{tabular}{|c|c|c|c|c|}
\hline \multirow{2}{*}{} & \multicolumn{2}{|c|}{ Mean +SD } & \multirow{2}{*}{ T-value } & P-value \\
\cline { 2 - 5 } & Cirrhotic group & Non-cirrhotic group & & \\
\hline IgG & $55.72 \pm 11.65$ & $41.87 \pm 10.42$ & 7.51 & $\mathrm{P}<0.05$ \\
\hline IgA & $51.43 \pm 10.86$ & $24.22 \pm 9.77$ & 9.86 & $\mathrm{P}<0.05$ \\
\hline
\end{tabular}

\section{Discussion}

Hepatitis C virus infection lead to liver cirrhosis in only $10 \%$ of patients [16]. However, H. Pylori presence in hepatic tissue could occur via a retrograde route from the duodenum or through the portal circulation. However, Rocha et al. [8] suggested that liver structural changes induce $H$. Pylori presence when liver cirrhosis occurs [8]. In this setting, a retrograde route, from the duodenum to the liver might be the underlying mechanism for H. pylori to colonize in liver tissue. It is worth noting that our results come in agreement Petrenkienë et al. [17] as all of our patients with $H$. pylori in liver were sero positive for anti-HP antibodies and patients negative for $H$. pylori DNA in liver tissue were also negative to anti-HP antibodies [17].

In our study, $H$. pylori prevalence was investigated using IgG and IgA as indicators for infection among patients with HCV either with cirrhosis or without cirrhosis this is consistent with many previous studies $[13,18-20]$. Also, in our study there were higher prevalence of $H$. pylori IgG and H. pylori IgA in cirrhotic than non-cirrhotic patients, these data agreed with many studies $[21,22]$. Moreover, these findings agreed with Pellicano et al. [22] mentioned that $89 \%$ of HCV cirrhotic patients had $H$. pylori antibodies [23]. In addition, Spinzi et al. [24] found that $86.5 \%$ of HCV cirrhotic patients had H. pylori antibodies with high prevalence of gastroduodenal ulcer in cirrhotic patients [24]. Similarly, Ponzetto et al. [25] proved that, the prevalence of $H$. pylori antibodies was $79.5 \%$ among HCV cirrhosis patients [25]. While, Vorobjova et al. [26] stated that antibody levels of $\mathrm{H}$. bilis/H. hepaticus were increased in sera of nighty patients with different chronic liver diseases [26]. However, Shavakhi et al. [27] reported that $73 \%$ of cirrhotic patients and $52 \%$ of control group had IgG antibody to $H$. pylori [27]. While, Nilsson et al. [28] stated that high level of H. hepaticus antibody in $8 \%$ of chronic liver diseases patients [28]. Also, Queiroz et al. [29] found an association between cirrhosis among HCV and H. pylori infection [29]. Moreover, this was in agreement with El-Masry et al. [30] who stated that 55.6\% of Egyptian HCV patients had H. pylori as co-infection [30]. Moreover, Sathar and colleagues mentioned that reported that $44.3 \%$ of cirrhotic patients with portal hypertensive gastropathy had $H$. pylori antibodies [31]. Furthermore, Wang et al. [32] reported that HCV patients had higher prevalence of $H$. pylori than those without HCV [32].

The possible mechanism of liver dysfunction due to $H$. pylori may be due to release of hepatic-specific toxin produced by several Helicobacter spp. that may have an aetiological role in progression of HCV-related hepatitis [33]. In the other hand Innocenti and colleagues said that the possible role of $H$. pylori playing in developing or progression of CHV cirrhosis because of the systemic inflammation and subsequent hepatic damage triggered via autoimmune response induced by $H$. pylori which was evident by higher seroprevalence of anti- $H$. pylori antibodies in HCV cirrhotic patients [34].

\section{Conclusion}

Helicobacter pylori infection antibodies are more prevalent among cirrhotic HCV patients than without cirrhosis. 


\section{Acknowledgment}

This work was funded by the Deanship of Scientific Research (DSR), King Abdulaziz University, Jeddah, under grant No. (142567-D1435). The authors, therefore, acknowledge with thanks DSR technical and financial support.

\section{References}

1. Enroth H, Engstrand L (2008) Helicobacter Pylori. International Encyclopedia of Public Health. 2008: 290-294.

2. Thrift AP, El-Serag HB, Kanwal F (2017) Global epidemiology and burden of HCV infection and HCV-related disease. Nat Rev Gastroenterol Hepatol 14(2): 122-132.

3. Esmat G, El-Bendary M, Zakarya S, Ela MA, Zalata K (2012) Role of Helicobacter pylori in patients with HCV-related chronic hepatitis and cirrhosis with or without hepato cellular carcinoma: possible association with disease progression. J Viral Hepat 19(7): 473-479.

4. Al- Mahtab M (2010) State of the globe: Helicobacter pylori and hepatitis C together hamper health. J Globe Inf Dis 2(1): 1-3.

5. Castéra L, Pedeboscq A, Rocha M, Le Bail B, Asencio C, et al. (2006) Relationship between the severity of hepatitis $C$ virus-related liver disease and the presence of Helicobacter species in the liver: a prospective study. World J Gastroenterol 12(45): 7278-7284.

6. de Magalhães Queiroz DM, Santos A (2001) Isolation of a Helicobacter strain from the human liver. Gastroenterology. 121(4): 1023-1024.

7. Furusyo N, Walaa AH, Eiraku K, Toyoda K, Ogawa E, et al. (2011) Treatment for Eradication of Helicobacter pylori Infection among Chronic Hepatitis C Patients. Gut Liver 5(4): 447-453.

8. Rocha M, Avenaud P, Ménard A, Le Bail B, Balabaud C, et al. (2005) Association of Helicobacter species with hepatitis C cirrhosis with or without hepato cellular carcinoma. Gut 54(3): 396-401.

9. Meyer-ter-Vehn T, Covacci A, Kist M, Pahl HL (2000) Helicobacter pylori activates mitogen-activated protein kinase cascades and induces expression of the proto-oncogenes c-fos and c-jun. J Biol Chem 275(21): 16064-16072.

10. Ponzetto A, Pellicano R, Leone N, Cutufia MA, Turrini F, et al. (2000) Helicobacter infection and cirrhosis in hepatitis $\mathrm{C}$ virus carriage: is it an innocent bystander or a troublemaker? Med Hypotheses 54(2): 275-277.

11. El-Masry S, El-Shahat M, Badra G, Aboel-Nour MF, Lotfy M (2010) Helicobacter pylori and Hepatitis C Virus Coinfection in Egyptian Patients. J Glob Infect Dis 2(1): 4-9.

12. Dore MP, Realdi G, Mura D, Graham DY, Sepulveda AR (2002) Helicobacter infection in patients with HCV-related chronic hepatitis, cirrhosis, and hepatocellular carcinoma. Dig Dis Sci 47(7): 1638-1643.

13. Queiroz DM, Rocha AM, Rocha GA, Cinque SM, Oliveira AG, et al. (2006) Association between Helicobacter pylori infection and cirrhosis in patients with chronic hepatitis C virus. Dig Dis Sci. 51(2): 370-373.

14. Krüttgen A, Horz HP, Weber-Heynemann J, Vucur M, Trautwein C, et al. (2012) Study on the association of Helicobacter species with viral hepatitis-induced hepatocellular carcinoma. Gut Microbes 3(3): 228233

15. Ponzetto A, Pellicano R, Redaelli A, Rizzetto M, Roffi L (2003) Helicobacter pylori infection in patients with Hepatitis C Virus positive chronic liver diseases. New Microbiol 26(4): 321-328.

16. Matthews J, Bini W (2004) Epidemiology, diagnosis and treatment of chronic hepatitis C. Journal of pharmacy practice. 17: 229-238.
17. Petrenkienë $V$, Vitkauskienë $A$, Jonaitis $L$, Kupèinskas L, Wadström $T$ (2004) Detection of Helicobacter spp. in liver biopsy specimens. Acta Medica Lituanica. 11 (3): 31-35.

18. Rahimkhani M, Ghofrani H (2008) Helicobacter pylori and peptic ulcer in cirrhotic patients. Pak J Med Sci 24(6): 849-852.

19. Shirin H, Bruck R, Kenet G (1999) Evaluation of the new immune chromatographic test for Helicobacter pylori IgG in elderly symptomatic patient. J Gastroentrol 34: 7-10.

20.Sakr S, Badrah G, Sheir R (2013) Histological and histo chemical alterations in liver of chronic hepatitis $\mathrm{C}$ patients with Helicobacter pylori infection. Biomedicine \& Pharmacotherapy 67: 367-374.

21. Ponzetto A, Pellicano R, Redaelli A (2003) Helicobacter pylori infection in patient with hepatitis $\mathrm{C}$ virus positive chronic liver diseases. New Microbiol 26(4): 321-328.

22. Pellicano R, Leone N, Berrutti M (2000) Helicobacter pylori seroprevelence in hepatitis $\mathrm{C}$ virus positive patient with cirrhosis. J Hepatology 33(4): 648-650.

23. Pellicano R, Leone N, Berrutti M, Cutufia MA, Fiorentino M, et al. (2000) Helicobacter pylori seroprevalence in hepatitis $\mathrm{C}$ virus positive patients with cirrhosis. J Hepatol 33(4): 648-650.

24. Spinzi G, Pellicano R, Minoli G, Terreni N, Cutufia MA, et al. (2001) Helicobacter pylori sero prevalence in hepatitis $\mathrm{C}$ virus positive patients with cirrhosis. The Como cross-sectional study. Panminerva Med 43(2): 85-87.

25. Ponzetto A, Pellicano R, Redaelli A, Rizzetto M, Roffi L (2003) Helicobacter pylori infection in patients with Hepatitis C Virus positive chronic liver diseases. New Microbiol 26(4): 321-328.

26. Vorobjova T, Nilsson I, Terjajev S, Granholm M, Lyyra M, et al. (2006) Serum antibodies to entero hepatic Helicobacter spp. in patients with chronic liver diseases and in a population with high prevalence of $\mathrm{H}$. pylori infection. Dig Liver Dis 38(3): 171-176.

27. Shavakhi A, Khodadustan M, Zafarghandi M, Gachkar L, Firozi M, et al. (2007) Seroprevalence of anti-helicobacter pylori antibodies in hepatitis B and C patients with cirrhosis: a case-control study. JRMS 12(6): 293-297.

28. Nilsson I, Lindgren S, Eriksson T, Wadstr"om T (2000) Serum antibodies to Helicobacter hepaticus and Helicobacter pylori in patients with chronic liver disease. Gut 46: 410-414.

29. Queiroz D, Rocha A, Rocha G, Cinque S, Oliveira A, et al. (2006) Association between Helicobacter pylori infection and cirrhosis in patients with chronic hepatitis C virus. Dig Dis Sci 51(2): 370-373.

30. El-Masry S, El-Shahat M, Badra G, Aboel-Nour M, Lotfy M (2010) Helicobacter pylori and hepatitis C virus coinfection in Egyptian patients. J Glob Infect Dis 2(1): 4-9.

31. Sathar S, Kunnathuparambil S, Sreesh S, Narayanan P, Vinayakumar K (2014) Helicobacter pylori infection in patients with liver cirrhosis: prevalence and association with portal hypertensive gastropathy. Ann Gastroenterol 27(1): 48-52.

32. Wang J, Li WT, Zheng YX, Zhao SS, Li N, et al. (2016) The Association between Helicobacter pylori Infection and Chronic Hepatitis C: A MetaAnalysis and Trial Sequential Analysis. Gastroenterol Res Pract 2016: 8780695 .

33. Taylor NS, Fox JG, Yan L (1995) In-vitro hepato toxic factor in Helicobacter hepticus. H. pylori and other Helicobacter species. J Med Microbial 42: 52.

34. Innocenti M, Thoreson AC, Ferrero RL, Stromberg E, Bolin I, et al. (2002) Helicobacter pylori-induced activation of human endothelial cells. Infect Immun 70: 4581-4590. 


\section{Your next submission with Juniper Publishers} will reach you the below assets

- Quality Editorial service

- Swift Peer Review

- Reprints availability

- E-prints Service

- Manuscript Podcast for convenient understanding

- Global attainment for your research

- Manuscript accessibility in different formats

( Pdf, E-pub, Full Text, Audio)

- Unceasing customer service

Track the below URL for one-step submission https://juniperpublishers.com/online-submission.php 